\title{
EFEKTIVITAS PENERAPAN PERATURAN WALIKOTA MAGELANG NOMOR 30 TAHUN 2020 TENTANG PEDOMAN ADAPTASI KEBIASAAN BARU PRODUKTIF DAN AMAN CORONA VIRUS DISEASE 2019 BAGI MASYARAKAT KOTA MAGELANG
}

\author{
Agus Tri Widodo ${ }^{凶}$ \\ Universitas Sebelas Maret Surakarta \\ $\triangle$ agusmagelang72@gmail.com
}

\begin{abstract}
In order to deal with the impact of Covid-19, both of central and regional governments synergize with each other to form the policies. Follow up the Keputusan Presiden Nomor 12 Tabun 2020 tentang Penetapan Bencana Nonalam Penyebaran Corona Virus Disease 2019 (COVID-19) sebagai Bencana Nasional, Magelang City Governments enact the Peraturan Walikota Magelang Nomor 30 Tabun 2020 Tentang Pedoman Adaptasi Kebiasaan Baru Produktif dan Aman Corona Virus Disease 2019 Bagi Masyarakat Kota Magelang. This article aims to discuss two things. First, reviewing the effectiveness of that regulation. Second, what efforts that need to be made to increase the effectiveness of the implementation of that regulation. In this article, the author argues that the implementation of Peraturan Walikota Magelang Nomor 30 Tabun 2020 is deemed ineffective and requires further efforts in its application to achieve the expected goals.
\end{abstract}

Keywords: covid-19; effectiveness; mayor regulation.

Dalam rangka menanggulangi dampak yang disebabkan oleh Covid-19, pemerintah pusat dan daerah saling bersinergi untuk membentuk kebijakan. Menindaklanjuti Keputusan Presiden Nomor 12 Tahun 2020 tentang Penetapan Bencana Nonalam Penyebaran Corona Virus Disease 2019 (COVID-19) sebagai Bencana Nasional, Pemerintah Daerah Kota Magelang mengundangkan Peraturan Walikota Magelang Nomor 30 Tahun 2020 Tentang Pedoman Adaptasi Kebiasaan Baru Produktif dan Aman Corona Virus Disease 2019 Bagi Masyarakat Kota Magelang. Artikel ini bertujuan untuk mendiskusikan dua hal. Pertama, meninjau efektivitas dari peraturan walikota tersebut. Kedua, upaya apa yang perlu dilakukan untuk meningkatkan efektivitas terhadap penerapan peraturan walikota tersebut. Dalam artikel ini, penulis beragumen bahwa penerapan peraturan walikota magelang nomor 30 tahun 2020 dirasa belum efektif dan membutuhkan upaya-upaya lanjutan dalam penerapannya untuk mencapai tujuan yang diharapkan.

Kata Kunci : covid-19; efektivitas; peraturan walikota. 


\section{INTRODUCTION}

Corona Virus Disease terdeteksi pertama kali di Kota Wuhan, Provinsi Hubei, China. World Health Organization (WHO) mengumumkan adanya kasus kluster pneumonia dengan etiologi yang tidak jelas pada 31 Desember 2019. Sebulan kemudian, tepatnya pada 30 Januari 2020, WHO menetapkan Covid-19 sebagai Public Health Emergency of International Concern (PHEIC) atau Kedaruratan Kesehatan Masyarakat yang Meresahkan Dunia (KKMMD). ${ }^{1}$ Virus ini kemudian menyebar ke seluruh penjuru dunia dan memberikan dampak yang sangat luas dalam berbagai aspek kehidupan.

Indonesia pun tidak luput dari serangan wabah ini. Indonesia pertama kali mengumumkan kasus Covid-19 pada 2 Maret 2020. Jumlah kasusnya terus bertambah hingga saat ini. Pertanggal 1 Januari 2021, tercatat 751.270 kasus positif Covid-19 dengan rincian 22.239 orang meninggal dunia dan 617.936 orang sembuh dari virus corona. ${ }^{2}$ Tidak hanya berdampak pada aspek kesehatan, pandemi ini juga berdampak pada aspek sosial, ekonomi, dan kesejahteraan masyarakat. Atas dasar itu, WHO kemudian menetapkan Covid-19 sebagai Global Pandemic pada 11 Maret 2020. Penerbitan Keputusan Presiden Nomor 12 Tahun 2020 tentang Penetapan Bencana Nonalam Penyebaran Corona Virus Disease 2019 (Covid-19) Sebagai Bencana Nasional merupakan upaya yang dilakukan oleh Pemerintah Indonesia dalam rangka merespon kebijakan WHO tersebut.

Dalam rangka menanggulangi semakin meluasnya dampak pandemi Covid-19, di dalam Keputusan Presiden Nomor 12 Tahun 2020 tentang Penetapan Bencana Nonalam Penyebaran Corona Virus Disease 2019 (COVID-19) sebagai Bencana Nasional khususnya pada dictum ketiga, gubernur, bupati, dan walikota sebagai Ketua Gugus Tugas Percepatan Penanganan Corona Virus Disease (Covid-19) di daerah, dalam menetapkan kebijakan masing-masing harus memperhatikan kebijakan Pemerintah Pusat.

Menindaklanjuti Keppres tersebut, Pemerintah Kota Magelang menetapkan Peraturan Walikota Magelang Nomor 30 Tahun 2020 tentang Pedoman Adaptasi Kebiasaan Baru Produktif dan Aman Corona Virus Disease 2019 Bagi Masyarakat Kota Magelang. Peraturan Walikota tersebut dibentuk atas petimbangan menjaga kelangsungan pelaksanaan tugas fungsi pemerintahan, pelayanan public, kegiatan perekonomian, dan sosial dengan tetap memprioritaskan kesehatan dan keselamatan. ${ }^{3}$ Sebagaimana dicantumkan dalam Pasal 2, Peraturan Walikota ini dimaksudkan sebagai pedoman pelaksanaan bagi semua pemangku kepentingan dalam beradaptasi pada situasi pandemi melalui perubahan perilaku dengan menerapkan protokol kesehatan secara ketat menuju masyarakat yang sehat, disiplin, produktif, dan aman Corona Virus Disease 2019.

Peraturan Walikota Magelang Nomor 30 Tahun 2020 ini telah berlaku semenjak tanggal diundangkannya pada 4 Agustus 2020. Setelah berlaku beberapa bulan, kini Indonesia mulai memasuki babak baru Covid-19. Oleh karenanya, perlu peraturan walikota

\footnotetext{
Kurniyanto, 2020, "Pandemi Corona Virus”, https://rsupsoeradji.id/pandemi-corona-virus/, diakses 1 Januari 2020

Herlina KD, 2020, "UPDATE Corona Indonesia, Jumat (1/1): Bertambah 8.072 Kasus Baru, ingat selalu 3M"

3 Peraturan Walikota Magelang Nomor 30 Tahun 2020 tentang Pedoman Adaptasi Kebiasaan Baru Produktif dan Aman Corona Virus Disease 2019 Bagi Masyarakat Kota Magelang.
} 
tersebut perlu ditinjau mengenai efektivitasnya. Berdasarkan uraian diatas, penelitian ini berfokus membahas 2 (dua) hal. Pertama, bagaimana efektivitas penerapan Peraturan Walikota Magelang Nomor 30 Tahun 2020. Kedua, upaya apa yang dapat dilakukan untuk meningkatkan kepatuhan terhadap kebijakan penanganan Covid-19 di Kota Magelang.

\section{Metode Penelitian}

Penelitian ini merupakan penelitian yuridis-empiris, penelitian ini berdasar pada teori-teori hukum, literatur yang relevan, dan peraturan perundang-undangan yang berlaku di masyarkat yang kemudian dikombinasikan dengan pengamatan atas implementasi di lapangan. Data yang digunakan dalam penelitian ini adalah data sekunder.

\section{RESULTS \& DISCUSSION}

\section{A. Kebijakan Pemerintah Kota Magelang dalam Penanganan Covid-19}

Bencana Covid-19 yang telah ditetapkan sebagai Global Pandemic perlu dilakukan penanganan secara holistik dari berbagai pihak, salah satunya dari sisi pemerintahan sebagai otoritas yang diberikan kewenangan oleh rakyat dalam mengurus kebutuhan dan melindungi rakyat dari segala ancaman. Dalam penanganan bencana tersebut Pemerintah Indonesia melakukan pembagian kewenangan untuk mengendalikan persebaran Covid-19 melalui berbagai kebijakan secara berlapis dari pemerintah pusat sampai dengan pemerintah daerah.

Dengan demikian maka diperlukan kerja sama antara pemerintah pusat dan pemerintah daerah dalam penerapan kebijakan karena tingkat efektivitass merupakan pencapaian yang telah disepakati sebagai usaha bersama ${ }^{4}$, sehingga koordinasi dan sinkronisasi diutamakan dalam pembuatan kebijakan.

Peraturan Walikota Magelang Nomor 30 Tahun 2020 tentang Pedoman Adaptasi Kebiasaan Baru Produktif dan Aman Corona Virus Disease 2019 Bagi Masyarakat Kota Magelang merupakan upaya dalam pengendalian penyebaran Covid-19 di Daerah, yang sampai dengan saat ini masih berlaku dan dijadikan patokan bagi masyarakat untuk berkegiatan. Yang mana dalam penyusunan Peraturan Walikota ini mendasarkan pada asas formal pembentukan peraturan perundang-undangan yang baik dengan mengedepankan kejelasan tujuan, urgensi pembentukan, implementatif dapat dilaksanakan, kedayagunaan dan kehasilgunaan, muatan yang tepat dan kejelasan rumusan. ${ }^{5}$

Untuk mengetahui kedayagunaan dan kehasilgunaan yang merupakan tujuan dalam penyusunan peraturan efektif atau tidak dalam penerapannya. H. Emerson mendefinisikan berkaitan dengan efektivitas sebagai pengukuran terhadap tercapainya suatu tujuan yang tetapkan sebagai indikator keberhasilan, ${ }^{6}$ dapat juga diartikan sebagai pencapaian tujuan dengan mengukur antara target dengan upaya yang telah dilakukan dengan perhitungan berdasarkan kuantitas, kualitas dan waktu pencapaian. ${ }^{7}$

4 Bernard H Russell. (1994). In Research Methods in Anthropology: Qualitative and Quantitative Approaches. California: SAGE Publications, Inc. dalam Idham Imam Seputra, Pengarub Implementasi Kebijakan Terbadap Efektivitas Penanggulangan Covid-19 Oleh Pemerintah Daerah Kerinci, Vol 7 No 2 Tahun 2020, hlm.411.

5 Nanda Novia Putri,et.al., Landasan dan Asas-Asas Pembentukan Peraturan Perundang-Undangan Yang Baik, Researchgate.

6 Soewarno Handayaningrat S., Pengantar Study Ilmu Administrasi dan Manajemen, Jakarta: CV. Haji Masagung. Hlm 16.

7 Idham Imam Seputra, Locit, hlm.412.

(c) Author(s). This work is licensed under a Creative Commons Attribution-NonCommercial-ShareAlike 4.0 International License. Published by Postgraduate Program, Master of Laws, Faculty of Law, Universitas Sebelas Maret, Indonesia 
Menurut Soerjono Soekanto memaparkan untuk mengetahui keefektifan terhadap suatu peraturan didasarkan terhadap lima faktor sebagai indikatornya, yang terdiri atas ${ }^{8}$ :

1. Faktor hukumnya sendiri;

2. Faktor penegak hukum, yakni pihak-pihak yang membentuk maupun menerapkan hukum;

3. Faktor sarana atau fasilitas yang mendukung penegakan hukum;

4. Faktor masyarakat, yakni lingkungan di mana hukum tersebut berlaku atau diterapkan; dan

5. Faktor kebudayaan, yakni sebagai hasil karya, cipta, dan rasa yang didasarkan pada karsa manusia di dalam pergaulan hidup.

Lima faktor tersebut saling berkaitan satu dengan yang lainnya karena merupakan esensi dari penegakan hukum serta merupakan tolak ukur bagi efektivitas penegakan hukum itu sendiri. Dari kelima faktor tersebut, masing-masing faktor memiliki indikator atas ukuran efektivitasnya.

Faktor hukum sebagaimana dimaksud pada angka 1 dijabarkan menjadi sebagai berikut ${ }^{9}$ :

a. Sistematisnya peraturan yang berkaitan;

b. Peraturan sudah sinkron baik secara horizontal maupun vertikal;

c. Ketersediaan peraturan sudah mencukupi secara kualitatif dan kuantitatifnya; dan

d. Penerbitan peraturan sudah sesuai dengan persyaratan yuridisnya,

keempat hal tersebut merupakan syarat yang harus terpenuhi secara kumulatif sehingga perlu dilakukan tinjauan mendalam dalam menganalisa suatu peraturan yang diberlakukan. Dari segi ini, Peraturan Walikota Magelang Nomor 30 Tahun 2020 telah disusun secara sistematis dengan memperhatikan sinkronisasi secara horizontal maupun vertikal guna menghindari pertentangan ataupun tumpang tindih antara peraturan yang satu dan yang lainnya. Perwal ini juga telah secara kualitatif dan kuantitatif mencukupi kebutuhan masyarakat guna menghadapi pandemi Covid-19. Penerbitan atas perwal ini juga telah memenuhi persyaratan yuridis yang ada. Sehingga dipandang dari segi hukumnya sendiri, sudah sesuai dengan formulasi penyusunan norma yang dipersyaratkan.

Faktor kedua mengenai penegak hukum, diperlukan aparat penegak hukum yang handal, terampil dan profesional dalam melaksanakan law enforcement terhadap penerapan peraturan yang kemudian dirinci sebagai berikut ${ }^{10}$ :

a. Sejauhmana petugas terikat dengan peraturan-peraturan yang ada;

b. Sampai batas mana petugas diperkenankan memberikan kebijaksanaan;

c. Teladan macam apa yang seharusnya diberikan petugas kepada masyarakat;

d. Sampai sejauhmana derajat sinkronisasi penugasan-penugasan yang diberikan kepada petugas sehingga terdapat batas kewenangan yang jelas.

Dalam penerapan Peraturan Walikota Magelang Nomor 30 Tahun 2020 sudah terdapat pengaturan yang jelas mengenai siapa yang berwenang menegakkan peraturan, pihak mana saja yang dapat bersinergi dalam penegakan aturan beserta sinkronisasi

\footnotetext{
8 Soerjono Soekanto, Faktor-Faktor yang Mempengarubi Penegakan Hukum, Jakarta : PT.RajaGrafindo Persada, 2008, hlm. 8.

${ }^{9}$ Soerjono Soekanto, Penegakan Hukum, Bandung : Bina Cipta, 1983, hlm, 80.

${ }^{10} \mathrm{Ibid}, \mathrm{hlm} 82$.
}

(C) Author(s). This work is licensed under a Creative Commons Attribution 4.0 International License . Published by Postgraduate Program, Master of Laws, Faculty of Law, Universitas Sebelas Maret, Indonesia 
penugasannya, sebagaimana yang tercantum dalam Pasal 28 bahwa untuk melakukan pengawasan, pembinaan dan penegakan hukum dilakukan oleh tim gabungan yang melibatkan unsur Kepolisian, Tentara Nasional Indonesia, tokoh masyarakat, dan tokoh agama. Yang dalam prakteknya ketika dalam melakukan penegakan terhadap pelanggar diberikan sanksi sosial berupa menyanyikan lagu kebangsaan, lari mengelilingi area tertentu, ataupun ikut dalam bersih-bersih kota, meskipun secara eksplisit hal tersebut tidak tercantum dalam Peraturan Walikota ini, akan tetapi hal itu dipandang perlu untuk memberikan efek malu ketika melakukan pelanggaran atas suatu aturan.

Ketiga, faktor mengenai ketersediaan sarana atau fasilitas yang mendukung penegakan hukum, maksudnya adalah sarana atau fasilitas yang sebagai modal dalam untuk mencapai efektivitas atas suatu peraturan sehingga berkontribusi bagi penegak hukum dalam melaksanakan tugas, dengan elemen sebagai berikut: ${ }^{11}$

a. Terpeliharanya prasarana yang telah ada;

b. Prediksi terhadap pengadaan prasarana;

c. Pelengkapan terhadap prasarana yang dibutuhkan;

d. Perbaikan terhadap prasarana yang rusak;

e. Perbaikan fungsi prasarana yang mengalami kendala agar dilancarkan;

f. Prasarana yang mengalami penurunan fungsi perlu ditingkatkan kembali.

Untuk penyediaan sarana dan prasarana penunjang memang belum dapat terpenuhi secara keseluruhan akan tetapi melalui dana insentif daerah maupun biaya tak terduga sudah mencoba dilakukan pemenuhan dimulai dari penyediaan Alat Pelindung Diri di berbagai tempat, perbaikan tempat-tempat umum dengan menyesuaikan dengan protokol kesehatan, dan fasilitas-fasilitas lainnya. Akan tetapi kenyataan di lapangan terhadap hal tersebut belum dapat didayagunakan sebagaimana mestinya oleh masyarakat, masih terdapat masyarakat yang abai atas hal-hal tersebut, yang rata-rata dilakukan oleh masyarakat usia remaja ataupun lingkungan sosial tertentu.

Faktor masyarakat sebagai pengukur efektivitas dijabarkan menjadi sebagai berikut: ${ }^{12}$

a. Faktor penyebab masyarakat tidak mematuhi aturan yang sudah baik;

b. Faktor penyebab masyarajat tidak mematuhi aturan padahal aturan baik dan aparat penegak hukum berwibawa;

c. Faktor penyebab masyarakat tidak mematuhi aturan baik, aparat berwibawa serta fasilitas mencukupi.

Berkaitan dengan implementasi Peraturan Walikota Magelang Nomor 30 Tahun 2020 tentang Pedoman Adaptasi Kebiasaan Baru Produktif dan Aman Corona Virus Disease 2019 Bagi Masyarakat Kota Magelang, pada kenyataannya belum membuahkan hasil yang maksimal hal ini ditandai dengan masih meningkatnya kasus Covid-19 dan masih terdapatnya kerumunan dan acara di masyarakat yang bersembunyi-sembunyi. Hal ini terjadi dikarenakan masyarakat belum mempunyai kesadaran yang baik terhadap bahaya Covid-19 meskipun operasi yustisi rutin dilaksanakan, dan kurangnya keteladanan yang dikarenakan adanya event pilkada serentak yang dimulai dengan berbagai macam kegiatan sebelumnya yang membawa asumsi bahwa keadaan sudah normal seperti sediakala sehingga memicu masyarakat untuk abai dalam penerapan protokol kesehatan.

11 Ibid.

12 Ibid.

(c) Author(s). This work is licensed under a Creative Commons Attribution-NonCommercial-ShareAlike 4.0 International License. Published by Postgraduate Program, Master of Laws, Faculty of Law, Universitas Sebelas Maret, Indonesia 
Teori efektivitas hukum yang dikemukakan oleh Soerjono Soekanto sejalan dengan pendapat dari Romli Atmasasmita ${ }^{13}$ bahwa ketidakefektifan dalam penerapan hukum bukan semata-mata terletak pada ketidakmampuan aparak penegaknya saja akan tetapi lebih kepada faktor sosialisasi peraturan dan edukasi kepada masyarakat yang lemah.

Dalam penerapan dari Peraturan Walikota Magelang Nomor 30 Tahun 2020 tentang Pedoman Adaptasi Kebiasaan Baru Produktif dan Aman Corona Virus Disease 2019 Bagi Masyarakat Kota Magelang sampai dengan saat ini dapat dikatakan belum mampu mencapai tujuan dari apa yang telah ditetapkan dalam Peraturan Walikota ini utamanya dari segi peran serta/ partisipasi masyarakat dan pemangku kepentingan/ tokoh untuk mencegah penularan Covid-19 hal ini sangat terlihat pada rangkaian event Pilkada Serentak tempo hari, dimana banyak terjadi kerumunan dibeberapa tempat yang tidak mematuhi ketentuan dalam Peraturan Walikota Magelang Nomor 30 Tahun 2020 yang dilakukan oleh para tokoh politik daerah.

\section{B. Upaya Meningkatkan Kepatuhan Terhadap Kebijakan Penanganan Covid-19}

Sebagai upaya untuk meningkatkan kepatuhan terhadap kebijakan penanganan Covid-19 dapat dilakukan dengan menggunakan dua aspek yaitu dengan melakukan rumusan hukum yang sesuai dengan hukum atau nilai-nilai yang hidup di masyarakat ataupun dengan meningkatkan kesadaran hukum masyarakat.

Berkaitan dengan perumusan hukum di era orde baru populer dengan adanya teori hukum pembangunan yang dikemukakan oleh Mochtar Kusumaatmadja yang mengelaborasi konsep law as a tool of social engineering sebagai penataan hukum nasional. ${ }^{14}$ Dalam teorinya, Mochtar memperagakan pola kerja sama dengan melibatkan keseluruhan stakeholders yang ada dalam komunitas sosial. ${ }^{15}$

Konsep teori hukum pembangunan menitik beratkan pada hukum sebagai sarana atau alat untuk melakukan perubahan perilaku masyarakat dengan tetap memperhatikan kondisi sosiologis dan nilai budaya yang hidup dalam masyarakat sehingga tidak terjadi gesekan yang luar biasa dalam melakukan perubahannya dengan tujuan untuk memelihara dan mempertahankan ketertiban di masyarakat. ${ }^{16}$

Sedangkan hukum sebagai aturan yang harus dituruti yang apabila dilanggar dapat mendatangkan penderitaan, membahayakan diri sendiri, atau harta benda yang dimilikinya, ${ }^{17}$ sehingga bagi setiap individu wajib untuk mentaati sesuai dengan apa yang telah ditetapkan agar ketertiban dan keamanan dalam pergaulan dapat terjaga dengan baik.

Dalam penerapan hukum kepada masyarakat yang homogen dengan berbagai latar belakang kehidupan, suku, ras, agama dan golongan, menurut Satjipto Rahardjo terdapat empat faktor kepatuhan hukum masyarakat, yaitu sebagai berikut ${ }^{18}$ :

1. Compliance merupakan kepatuhan yang didasarkan pada harapan akan suatu imbalan dan usaha untuk menghidarkan diri dari hukuman yang mungkin dikenakan apabila seseorang melanggar ketentuan hukum. Adanya pengawasan yang ketat terhadap kaidah hukum tersebut;

13 Romli Atmasasmita, Reformasi Hukum, Hak Asasi Manusia dan Penegakan Hukum, Bandung: mandar maju, 2011, hl m 55 .

14 Saifullah, Dinamika Teori Hukum "Sebuah Pembacaan Kritis Paradigmatik”, (Yogyakarta: Pustaka Pelajar, 2018), blm. 87.

15 Wacipto Setiadi, Pembangunan Hukum Dalam Rangka Peningkatan Supremasi Hukum, Jurnal Rechts Vinding: Media Pembinaan Hukum Nasional 1, no. 1, 2012, hlm. 8

16 Ibid, hlm 89-90.

17 S.T. Kansil, Pengantar Ilmu Hukum dan Tata Hukum Indonesia, Balai Pustaka, Jakarta, 1992, hlm. 12.

18 Achmad Ali, Menguak. Teori Hukum (Legal Theory) dan Teori Peradilan (Judicial Prudence) termasuk Interpretasi Undangundang (Legisprudence), (Jakarta : Kencana, 2009), hlm. 347-348

(C) Author(s). This work is licensed under a Creative Commons Attribution 4.0 International License . Published by Postgraduate Program, Master of Laws, Faculty of Law, Universitas Sebelas Maret, Indonesia 
2. Identification terjadi bila kepatuhan terhadap kaidah hukum ada bukan karena nilai intrinsiknya, akan tetapi agar keanggotaan kelompok tetap terjaga serta ada hubungan baik dengn mereka yang diberi wewenang untuk menerapkan kaidah kaidah hukum tersebut;

3. Internalization yakni seseroang mematuhi kaidah kaidah hukum dikarenakan secara intrinsik kepatuhan tadi mempunyai imbalan. Isinya sesuai dengan nilai nilainya dari pribadi yang bersangkutan;

4. Kepentingan-kepentingan para warga yang terjamin oleh wadah hukum yang ada.

Seyogyanya dalam pengendalian Covid-19 dalam perumusan kebijakan perlu memperhatikan kedua hal tersebut di atas supaya ketika membuat kebijakan pada saat diterapkan implementatif dan memenuhi rasa keadilan di masyarakat karena telah sesuai dengan nilai-nilai yang hidup dimasyarakat dan pemerintah sebagai pihak yang berwenang dalam menetapkan kebijakan, sehingga masyarakat merasa ada jaminan terhadap keselamatannya serta dalam perumusan kebijakan seharusnya melihat aspek-aspek potensi kepatuhan di masyarakat utamanya terkait substansi reward and punishment bagi yang patuh dan melanggar serta keterlibatan masyarakat/ peran serta masyarakat dalam penerapan hukumnya, sehingga setiap individu akan memiliki rasa tanggung jawab terhadap keterlaksanaan peraturan tersebut.

\section{CONCLUSION}

Dalam implementasi Peraturan Walikota Magelang Nomor 30 Tahun 2020 tentang Pedoman Adaptasi Kebiasaan Baru Produktif dan Aman Corona Virus Disease 2019 Bagi Masyarakat Kota Magelang belum dapat dikatakan efektif apabila dilakukan pengamatan dengan mendasarkan pada teori efektivitas hukum dari Soerjono Soekanto. Hal tersebut dikarenakan masih lemahnya kesadaran masyarakat untuk mematuhi peraturan tersebut dan dengan adanya Pilkada Serentak pada awal Desember berkontribusi pola ketidakpatuhan dari masyarakat dan para pemangku kepentingan belum dapat menjadi contoh yang baik dalam implementasi Peraturan Walikota tersebut. Apabila ditinjau dari jumlah kasus Covid-19 yang terjadi, pada tanggal 6 Juni 2020 terdapat 24 kasus positif dan 10 meninggal kemudian pada tanggal 27 Desember 2020 terdapat 1123 kasus positif dan 113 meninggal. ${ }^{19}$

Untuk meningkatkan efektivitas sebuah peraturan harus ada kerja sama antar stakeholder dalam suatu komunitas dengan mengakomodasi nilai yang hidup di masyarakat dengan memperhatikan kaidah sosial lainnya sehingga fungsi hukum sebagai sarana pembaruan pergaulan di masyarakat dapat tercapai. Dengan adanya beberapa hal tersebut maka masyarakat yang menjadi subjek ataupun objek dari peraturan yang di tetapkan merasa kepentingan-kepentingan yang dibutuhkan telah terakomodir sehingga dengan sendirinya akan meningkatkan kesadaran hukumnya dan kepatuhan terhadap aturan tersebut.

19 Sumber infografis Covid-19 Kota Magelang, yang dipublikasikan oleh Dinas Komunikasi, Informatika dan Statistik Kota Magelang.

(c) Author(s). This work is licensed under a Creative Commons Attribution-NonCommercial-ShareAlike 4.0 International License. Published by Postgraduate Program, Master of Laws, Faculty of Law, Universitas Sebelas Maret, Indonesia 


\section{REFERENCES}

Ali, Achmad, 2009, Menguak Teori Hukum (Legal Theory) dan Teori Peradilan (Judicial Prudence) termasuk Interpretasi Undang-undang (Legisprudence), Jakarta : Kencana.

Atmasasmita, Romli, 2011, Reformasi Hukum, Hak Asasi Manusia dan Penegakan Hukum, Bandung: mandar maju.

Handayaningrat, Soewarno., 2016, Pengantar Studi Ilmu Administrasi dan Manajemen, Jakarta: CV. Haji Masagung.

Kansil, S.T., 1992, Pengantar Ilmu Hukum Dan Tata Hukum Indonesia, Jakarta: Balai Pustaka.

Putri, Nanda Novia ,et.al., "Landasan dan Asas-Asas Pembentukan Peraturan PerundangUndangan Yang Baik", Researchgate.

Saifullah, 2018, Dinamika Teori Hukum "Sebuah Pembacaan Kritis Paradigmatik", Yogyakarta: Pustaka Pelajar.

Seputra, Idham Imam, 2020, "Pengaruh Implementasi Kebijakan Terhadap efektivitas penanggulangan Covid-19 oleh pemerintah daerah kerinci," Vol 7 No 2.

Setiadi, Wacipto Setiadi, 2012, "Pembangunan Hukum Dalam Rangka Peningkatan Supremasi Hukum”, Jurnal Rechts Vinding: Media Pembinaan Hukum Nasional 1, no. 1.

Soekanto, Soerjono, 1983, Penegakan Hukum, Bandung: Bina Cipta.

Soekanto, Soerjono, 2008, Faktor-Faktor yang Mempengaruhi Penegakan Hukum, Jakarta: PT.Raja Grafindo Persada.

Kurniyanto, 2020, "Pandemi Corona Virus", https://rsupsoeradji.id/pandemi-coronavirus/, diakses 1 Januari 2020

Herlina KD, 2020, “UPDATE Corona Indonesia, Jumat (1/1): Bertambah 8.072 Kasus Baru, ingat selalu 3M"

Peraturan Walikota Magelang Nomor 30 Tahun 2020 tentang Pedoman Adaptasi Kebiasaan Baru Produktif dan Aman Corona Virus Disease 2019 Bagi Masyarakat Kota Magelang. 